\title{
Oral health evaluation of cardiac patients admitted to cardiovascular pre- surgery intervention
}

\author{
Saúde bucal de pacientes cardiopatas internados em pré- intervenção de cirurgia cardiovascular
}

\author{
Cristhiane Olívia Ferreira do AMARAL ${ }^{1}$ \\ Luana Calvo PEREIRA' \\ Nayara Amigo GUY ${ }^{1}$ \\ Marcelo Sávio Paiva do AMARAL FILHO² \\ Gustavo de Almeida LOGAR ${ }^{1}$ \\ Fabiana Gouveia STRAIOTO'
}

\section{ABSTRACT}

\section{Objective}

To assess the oral health status of patients admitted to pre-intervention heart surgery, observing the need index concerning invasive treatment

\section{Methods}

hospitalized volunteers in number of 75 were evaluated in order to be investigated concerning which systemic changes were occurring, the patients' oral health conditions as well as the need for invasive dental procedures.

\section{Results}

Volunteers analyzed in the study were: $69.3 \%$ male and 30.7\% female. As for the reason for hospitalization were: valvuloplasty (41.3\%), coronary artery bypass surgery (24\%), pacemaker implantation (16\%), cardiac catheterization (8\%), placement of stent (6.6\%), congenital heart disease (4\%). The associated systemic changes were: hypertension (54.6\%), diabetes mellitus (20.0\%), hypertension and diabetes mellitus (13.3\%). Most patients presented the need to undergo invasive dental treatment procedures such as: Periodontal (58.6\%), Restorative Dentistry (26.6\%), surgical (18.6\%), endodontic (12\%), dental pain source $(2,6 \%)$, abscess presence $(1.3 \%)$.

\section{Conclusion}

The oral health status of the patients was considered poor, a significant number of patients at the time of the oral examination, needed some type of invasive dental treatment and the oral environment adequacy indicated dental condition which may cause the formation of infectious sites which in turn can trigger complications both in the oral cavity and general health, as well.

Indexing terms: Dental care. Heart diseases. Preoperative care. Surgical procedures.

\section{RESUMO}

\section{Objetivo}

Avaliar a condição de saúde bucal dos pacientes internados em pré- intervenção de cirurgia cardíaca, observando o índice de necessidade de tratamento invasivo.

\section{Métodos}

Foram avaliados 75 voluntários hospitalizados, investigando quais as alterações sistêmicas, as condições de saúde bucal e avaliando a necessidades de procedimentos odontológicos invasivos.

\section{Resultados}

Os voluntários analisados no estudo foram: 69,3\% do gênero masculino e 30,7\% do gênero feminino. Quanto ao motivo de internação foram: valvuloplastia (41,3\%), cirurgia de revascularização do miocárdio (24\%), implante de marcapasso (16\%), cateterismo cardíaco (8\%), colocação de Stent $(6,6 \%)$, cardiopatia congênita $(4 \%)$. As alterações sistêmicas associadas: hipertensão arterial $(54,6 \%)$, diabetes mellitus $(20,0 \%)$, hipertensão arterial e diabetes mellitus (13,3\%). A maioria dos pacientes apresentaram necessidade de realização de tratamento odontológico invasivo: periodontal $(58,6 \%)$, restaurador $(26,6 \%)$, cirúrgico $(18,6 \%)$, endodôntico $(12 \%)$, dor de origem odontológica $(2,6 \%)$, presença abcesso $(1,3 \%)$.

\section{Conclusão}

A condição de saúde bucal dos pacientes avaliados foi considerada deficiente, um número significativo de pacientes, no ato do exame bucal, necessitava de algum tipo de tratamento odontológico invasivo e de adequação do meio bucal indicado condição dentária com possibilidade de formação de focos infecciosos, podendo levar a complicações na cavidade bucal e saúde geral.

Termos de indexação: Assistência odontológica. Cardiopatias. Cuidados pré-operatórios. Procedimentos cirúrgicos operatórios

\footnotetext{
${ }^{1}$ Universidade do Oeste Paulista, Faculdade de Odontologia. Rua José Bongiovani, 700, Cidade Universitária, 19050-920 Presidente Prudente, SP, Brasil .Correspondência para / Correspondence to: COF AMARAL. E-mail: <crisamaral@unoeste.br>.

${ }^{2}$ Universidade do Oeste Paulista, Faculdade de Medicina. Presidente Prudente, SP, Brasil.
} 


\section{INTRODUCTION}

Cardiovascular surgery is performed in order to repair damage to the heart or in the great vessels attached to it. There are several types of cardiovascular surgery: myocardial revascularization, correction of valvular diseases such as their repair or replacement, diseases of the aorta, correction of congenital heart disease, cardiac pacemaker implantation and heart transplant ${ }^{1}$.

Preoperative patients in cardiac surgery must provide an adequate standard of oral health, without the presence of focal dental infections or triggering infectious foci in the oral cavity since the mouth may be the main gateway-causing microorganisms of Infective Endocarditis (IE) $)^{2}$, a disease in which infectious agents colonize endocardial surfaces, producing inflammation and damage ${ }^{3}$. The introduction of bacteria into the blood stream can lead to a transient bacteremia, enabling the adhesion of microorganisms in previously committed cardiac tissues ${ }^{4-8}$. IE can be triggered starting from invasive procedures in certain patients with various heart conditions such as prosthetic heart valves, congenital heart disease, previous endocarditis, acquired valvar dysfunction, mitral valve prolapse with valvar regurgitation, among others ${ }^{5-8}$.

Periodontal disease is presented both as a pathogenic microorganism reservoir and bacteremia dissemination, therefore, the implementation of educational practices designed to promote oral health and reduce biofilm should be a priority in these patients ${ }^{9-11}$. Associated with this, it must be mentioned that systemic changes that result in reduced salivary flow related to the use of certain medications such as beta-blockers lead to oral disease enhancement ${ }^{12}$. Dental health professionals must then be familiar with their patient's medical history, type of heart disease and its severity, drug interactions and their cardiovascular repercussions ${ }^{13-15}$.

Patients requiring cardiovascular surgery should be evaluated and should undergo dental treatment for suitability and maintaining proper oral environment in the pre and post-surgical periods, since the existence of a focus of oral infectious may be responsible for systemic complications ${ }^{16-17}$.

The care of a cardiac patient requires planning, so that complications and risks can be avoided during the treatment. Care protocols must be followed, such as effective communication between the dental and the cardiology team, history taking based on disease severity and patient adherence to medical follow-up, vital signs check, appointment length, correct choice of anesthetic and dosage within safety limits ${ }^{18-20}$. Another important precaution is to check the use of anticoagulants and antiplatelet agents, which can lead to excessive bleeding during surgical procedures. Patients with a history of cancer treated with radiation in the thoracic region may have compromised heart valves or coronary arteries and the use of antibiotic prophylaxis may be recommended when undergoing invasive dental procedures ${ }^{21}$.

It is crucial that the dental approach to cardiac patients at the undergraduate Dentistry courses is taught so as as to promote continued education in both public and private health sectors, ensuring adequate knowledge on heart disease and Dentistry for safe patient care ${ }^{22-24}$.

This study was justified on the lack of research and data on the oral health condition of pre-surgery cardiac patients. Therefore, the aim of this study was to evaluate the oral health of cardiac patients admitted for pre-intervention heart surgery observing invasive dental treatment index needs.

\section{METHODS}

\section{Study design}

Volunteers from a convenience sample were assessed by structured interview application in a crosssectional, observational study where systemic conditions were evaluated. Oral-dental physical examination was performed in order to evaluate patients' oral health conditions. The survey was conducted after approval of the Research Ethics Committee (protocol No. 156355). Patients who participated in this research were informed of the purpose of the study, as well as the methods used. Only then did they sign the consent form, as established by the Ethics in Human Research Resolution 466/2012 of the National Health Council of Brazil.

\section{Study and reference population}

This study was conducted at the Cardiology ward of the Regional Hospital in the city of Presidente Prudente, State of São Paulo, Brazil. The sample consisted of 75 adult patients, 23 females and 52 males aged 18 to 88 years, diagnosed with cardiovascular disease and hospitalized in preparation for cardiovascular surgery. Patients were selected based on a convenience sample, exclusion criteria was due to clinical research and those who have not shown interest in participating.

\section{Interview and assessment of oral health}

The volunteers were informed of the purpose of the research and after acceptance and signature of the free 
and informed consent, the interview was conducted, with questions addressed as such: patient's knowledge of infective endocarditis, satisfaction with the quality of oral health and dental esthetics and if they carried an oral hygiene kit with them in the hospital, patient identification data, type of underlying disease, presence of other associated pathology and finally whether medication use was properly authorized by the hospital and medical ethics committee to be taken from the patient's record.

After the interview, the patients underwent assessment of oral health concerning dental check-ups as well as periodontal and oral mucosa. The research question was: What is the quality of oral health presented by cardiac patients prior to cardiovascular surgery?

The degree of involvement of the teeth that needed invasive approaches was measured by the Invasive Needs Index $(\mathrm{INI})^{25}$, which is classified into types 0-6 treatments, according to the potential risk of infectious foci: 0 . oral cavity without any need for invasive treatment. 1. Restorative treatment indicated - acute caries restoration which fell or broke. 2. Endodontic treatment indicated. 3. Exodontia indicated. 4. Periodontal treatment (calculus or gingivitis). 5. Presence of periapical or periodontal abscess. 6. Pain of dental origin.

\section{Statistical analysis}

The data were tabulated and presented as descriptive statistics showing the mean values, standard deviations and frequencies (Excel, Microsoft).

\section{RESULTS}

The sample of 75 volunteers consisted of : 52 (69.3\%) males and 23 females (30.7\%), aged $18-88$ years (60 \pm 14 years) with their respective reason for admission for the surgical. Table 1 shows the descriptions of their answers. Valvuloplasty surgery was the most prevalent among the reasons for hospitalization.

Table 1. Data frequency based on the reason for hospitalization for surgical procedure $(n=75)$.

\begin{tabular}{lc}
\hline Surgical intervention & Frequency \\
\hline Congenital cardiopathy & $3(4.0 \%)$ \\
Stent Placement - Angioplasty & $5(6.6 \%)$ \\
Cardiac catheterization - Coronary angiography & $6(8.0 \%)$ \\
Pacemaker implantation & $12(16 \%)$ \\
Myocardial revascularization surgery & $18(24 \%)$ \\
Valvuloplasty & $31(41.3 \%)$ \\
TOTAL & $75(100 \%)$ \\
\hline
\end{tabular}

The volunteers were evaluated for the presence of other relevant systemic changes, 9 patients (12\%) did not have any systemic change besides the established heart disease, however $66(88 \%)$ of the volunteers presented one or more diseases associated with heart disease. The description of systemic changes found is shown in Table 2 .

Table 2. Frequency of one or more reports associated with other disease than cardiopathy. $(n=75)$.

\begin{tabular}{lc}
\hline Associated disease & Frequency \\
\hline Arterial hypertension & $41(54.6 \%)$ \\
Diabetes mellitus & $15(20.0 \%)$ \\
Arterial hypertension and Diabetes mellitus & $10(13.3 \%)$ \\
Patients with no associated disease & $9(12 \%)$ \\
TOTAL & $75(100 \%)$ \\
\hline
\end{tabular}

Concerning the volunteers' perception of their oral health, the majority (43\%) reported to be good, while only $12 \%$ reported it to be bad.

Table 3. Frequency of assessment of self-perceived quality of oral health $(n=75)$ :

\begin{tabular}{lc}
\hline Self oral health -perception (profile) & Frequency \\
Excellent & $6(8.0 \%)$ \\
Good & $32(42.6 \%)$ \\
Regular & $28(37.3 \%)$ \\
Bad & $9(12 \%)$ \\
Total & $75(100 \%)$ \\
\hline
\end{tabular}

Volunteers were assessed for knowledge of infective endocarditis, only $8(10.6 \%)$ stated they knew what it was and 67 (89.3\%) did not show any knowledge about it. Concerning whether they carried an oral hygiene kit containing toothbrush, dental floss and toothpaste during the time they were hospitalized, 61 (81.3\%) of the volunteers said they had material for oral hygiene, while 14 other volunteers (18.6\%) said they had not taken oral hygiene kit to hospital.

The volunteers were evaluated regarding the need for invasive dental treatment and $31(41.3 \%)$ required no invasive or rehabilitation treatment. However 44 (58.6\%) of the volunteers had one or more need for dental treatment as described in Table 4. It is noteworthy that only two volunteers reported pain from dental origin at the time of the interview and $23(30.6 \%)$ of the volunteers wore full dentures. 
Table 4. Dental needs identified in the evaluated volunteers $(n=75)$.

\begin{tabular}{lc}
\hline Dental needs & Frequency \\
\hline No invasive or rehab dental treatment need & $31(41.3 \%)$ \\
Periodontal treatment indicated & $44(58.6 \%)$ \\
Restorative treatment indicated & $20(26.6 \%)$ \\
Surgical treatment - Exodontia indicated & $14(18.6 \%)$ \\
Endodontic treatment & $9(12 \%)$ \\
Pain from dental origin & $2(2.6 \%)$ \\
Abscess & $1(1.3 \%)$ \\
Total showing invasive dental treatment need & $44(58.6 \%)$ \\
\hline
\end{tabular}

\section{DISCUSSION}

The study showed a prevalence of cardiovascular disorders in males (69.3\%). This result is confirmed by studies reporting prevalence of men diagnosed with heart disease however the literature suggests that women older than 45 year after menopause may have greater cardiovascular risks ${ }^{24}$. The evaluated hospitalized patients needed several types of heart surgery and the majority was indicated for heart valve repair, which is known to increase the risk for IE when antibiotic prophylaxis is not given $^{5,8}$

According to the 1997 Protocol of the American Heart Association (AHA), antibiotic prophylaxis is recommended and they classify Infective Endocarditis risk as: high, moderate or low. Some considerations were reevaluated in 2007 by the "Council of Rheumatic Fever, Infective Endocarditis and AHA Kawasaki disease", which introduced the need for antibiotic prophylaxis as it should be performed only in cardiac conditions considered as high risk for IE, which include prosthetic heart valves, previous history of IE, congenital heart disease (CHD), unrepaired cyanotic CHD, congenital heart disease repaired with prosthetic device, CHD repaired with residual defects and patients who received heart transplant and developed cardiac valvulopathy ${ }^{5,8}$.

The Association of Heart Disease Clinics of the Heart Institute (InCor) analyzed the AHA new statement and embraced the 1997 guidelines for Brazil, based on the fact that there are many patients who present valvar lesions due to rheumatic disease and also patients with numerous oral sites that may lead $\mathrm{IE}^{8}$. This study demonstrated the profile of patients with poor oral health condition.

Regarding knowledge on IE, results showed that $89.3 \%$ of respondents were unaware of the risk of complications. For those presenting poor oral health, this crucial systemic situation can bring severe impairment ${ }^{24}$.

In addition to the concern for IE prevention in these patients, it should be noted that they are often taking oral anticoagulants ${ }^{18}$, since most patients undergoing cardiovascular surgery, mainly valvuloplasty $(41 \%)$, require use of oral anticoagulants after surgery. In patients with poor oral health, once there is need for tooth extractions, it is of utmost importance that a specific treatment plan for surgical approach be performed.

Most of the volunteers presented co-morbidities, therefore requiring combination of different dental care protocols to cater for their systemic condition when performing invasive dental treatment. Effective communication between the cardiology and the dental teams is essential for treatment planning to minimize risks and complications. Performing oral surgery in a hospital environment should be considered for those patients with greater systemic involvement ${ }^{15}$.

Regarding self-perception of oral health quality, most patients stated to have good oral health, which did not match the findings from the intraoral examination, as only 31 subjects (41.3\%) showed no dental treatment need whereas 44 volunteers $(58.6 \%)$ required one or more invasive dental treatments ${ }^{2}$.

According to the epidemiological study on the Brazilian oral health conditions, $22 \%$ of adults and less than $8 \%$ of the elderly present periodontal health ${ }^{8}$, which confirms the high prevalence of periodontal problems found in the patients evaluated. All volunteers, except those who wore dentures, needed periodontal treatment. The literature presents data on the correlation between periodontal disease and cardiovascular disease, whereas periodontal disease and poor oral health have become prevalent in cardiac patients ${ }^{10,23-24}$

The oral health status of these patients are probably a result of poor access to health services. Multidisciplinary teams are responsible for health care at different levels of complexity, so it is imperative that dental professionals are part of such teams in hospitals.

\section{CONCLUSION}

Most individuals diagnosed with heart disease assessed in this study were male with a mean age 60 years, admitted for valvuloplasty. Most volunteers presented with heart disease associated with hypertension and diabetes. Their oral health status was considered poor, needing some type of invasive dental treatment. Their 
oral environment showed infectious foci formation, which may lead to complications both in the oral cavity and systemically.

\section{Collaborators}

COF AMARAL, lead author, design, advisor, literature review and writing of the article. LC PEREIRA and NA GUY participated in the data collection, dental and oral

\section{REFERENCES}

1. Lisboa LAF, Moreira LFP, Mejia OV, Dallan LAO, Pablo MA Pomerantzeff RC, et al. Evolução da cirurgia cardiovascular no Instituto do Coração: análise de 71.305 operações. Arq Bras Cardiol. 2009;94(2):162-8. doi: 10.1590/S0066$782 \times 2010000200006$

2. Carmona LT, Dios PD, Scolly C. Efficacy of antibiotic regimens for theprevention of bacterial endocarditis of bucal origin. J Dent Res. 2007;86(12):1142-1159. doi: 10.1177/154405910708601203

3. Rocha LMA, Oliveira PRD, Santos PB, Jesus LA, Stefani CM. Conhecimentos e condutas para prevenção da endocardite infecciosa entre cirurgiões-dentistas e acadêmicos de odontologia. Robrac. 2008:17(44):146-153.

4. Nascimento ER, Anjos neto filho M. Endocardite bacteriana em odontologia: doença e profilaxia medicamentosa. Uningá Review. 2012;12(2):136-45.

5. Branco-de-Almeida LS, Castro ML, Cogo K, Rosalen PL, Andrade ED, Franco GCN. Profilaxia da endocardite infecciosa: recomendações atuais a "American Heart Association (AHA)". Rev Periodontia. 2009;19(4):7-10.

6. Nascimento EM, Santos MF, Pinto TCA, Cavalcanti SDLB, Fontes LBC, Garcia AFG. Abordagem odontológica de pacientes com risco de endocardite: um estudo de intervenção. Odonto. 2011;19(37):107-16. doi: 10.15603/2176-1000

7. Tarasoutchi F, Montera MW, Grinberg M, Barbosa MR, Piñeiro DJ, Sánchez CRM et al. Diretriz Brasileira de Valvopatias - SBC 2011/ I Diretriz Interamericana de Valvopatias. Arq Bras Cardiol. 2011;97(5):1-67

8. Santos PSS, Soares Junior LAV. Medicina bucal a prática na odontologia hospitalar. São Paulo: Santos; 2012.

9. Neves ILI, Ávila WS, Neves RS, Giorgi DMA, Santos JFK, Oliveira Filho RM, et al. Monitorização materno-fetal durante procedimento odontológico em portadora de cardiopatia valvar. Arq bras Cardiol. 2009; 93(5):430-472. doi: 10.1590/S0066782X2009001100005

10. Guizoni J, Taveira L, Pereira J, Campos M. Doença periodontal como fator coadjuvante para o desenvolvimento do acidente vascular encefálico e arterosclerose. Rev Facul Odontol UPF. 2010;13(3):83-7. doi: 10.5335/rfo.v13i3.637 clinical tests, dental appointments, and writing the article. MSP AMARAL FILHO, was responsible for monitoring the hospitalized patients's follow-up during the research, checking records, collecting systemic data and writing the article. GA LOGAR guided the hospital practice and participated in the hospitalized patients' follow-up, checking records, collecting systemic data and writing the article. FG STRAIOTO was responsible for part of the analysis of results and discussion of the results and writing the article.

11. Ramos $M M B$, de Mendonça $M R$, Pellizzer EP, Okamoto $A C$ Júnior E GJ.20. Associação entre a doença periodontal e doenças sistêmicas crônicas-revisão de literatura. Arch Health Invest. 2013;2(1):24-31

12. Timerman L, Andrade J, Romito GA, Piegas LS. Avaliação da condição periodontal entre gestantes saudáveis e cardiopatas: estudo piloto. Rev Periodontia. 2007;17(4):65-69.

13. Naghettini $A V$, Belem JM, Salgado CM, Vasconcelos Júnior HM Seronni EMX, Junqueira $A L$, et al. Avaliação dos fatores de risco e proteção associados à elevação da pressão arterial em crianças. Arq Bras Cardiol. 2010;94(4):486-91. doi: 10.1590/S0066$782 \times 2010005000020$

14. Barros MNF, Gaujac C, Trento CL, Andrade MCV. Tratamento de pacientes cardiopatas na clínica odontológica. Rev Saúde Pesq. 2011;4(1):109-14.

15. Esteves JC, Simão FB, Ricieri C, Fattah CMR, Santos PSS, Aranega AM. Assistência cirúrgico-odontológica a pacientes com história de infarto do miocárdio. RGO, Rev Gaúch Odontol. 2011;59(2):285-91.

16. Oliveira FE, Guerra EE, Pitrez FAB, Fernandes FM, Rosito GBA Gonzáles $\mathrm{HE}$, et al. Avaliação pré-operatória e cuidados em cirurgia eletiva: recomendações baseadas em evidências. Rev AMRIGS. 2010;54(2):240-58

17. Klüppel LE, Hochuli-Vieira E, Carlos E, Gabrielli MAC, Pereira Filho VA. Avaliação pré-operatória de pacientes cardiopatas em odontologia. Rev ABO Nac. 2007;14(6):360-3.

18. Silva JM, Marceliano MFV, Silva PDAR, Souza PARS, Lamarão SMS Infecção endodôntica como fator de risco para manifestações sistêmicas: revisão da literatura. Rev Odontol UNESP. 2007;36(4):357-64.

19. Perez FEG, Rocha RG, Carnaval TG, Borsatti MA, Alegretti CE. Efeitos cardiovasculares da anestesia local de prilocaína 3\% com felipressina e lidocaína 2\% em normotensos. RPG Rev Pós Grad. 2011:18(3):134-9.

20. Souza LMA, Ramacciato JC, Mota RHL. Uso de anestésicos locais em pacientes idosos. RGO, Rev Gaúch Odontol. 2011;59(0):25-30

21. Friedlander $A H$, Sung EC, Child JS. Radiation-induced heart disease after Hodgkin's disease and breast cancer treatment: dental implications. J Am Dent Assoc. 2003;134(12):1615-20. doi: 10.14219/jada.archive.2003.0108 
22. Rocha CAS, Rocha MS, Sprovieri SRS. O que há de novo na profilaxia da endocardite bacteriana. Deve-se mudar a conduta atual? Rev Soc Bras Clin Med. 2009;7(6):418-421.

23. Nicolosi LN, Lewin PG, Giglio MJE. Parâmetros periodontais em pacientes com doença isquêmica do coração. Rev Odontol Argent Asoc. 2004;92(2):169-73.

24. Souza DO. Condições de saúde bucal de pacientes cardiopatas adultos internados no Hospital Geral Ana Nery em pré-operatório de cirurgia cardíaca [dissertação]. Salvador: Universidade Federal da Bahia; 2010.
25. Lobão DS. Condições de saúde bucal e acompanhamento odontológico de crianças portadoras de leucemia Linfocítica aguda [dissertação]. Belo Horizonte: Universidade Federal de Minas Gerais; 2006.

Received on: 16/4/2015

Final version resubmitted on: 29/2/2016

Approved on: 15/3/2016 